Małgorzata Janiak

Uniwersytet Jagielloński

Instytut Informacji Naukowej i Bibliotekoznawstwa

\title{
Zarządzanie informacją: zmiany w procesie kształcenia w Instytucie Informacji Naukowej \\ i Bibliotekoznawstwa \\ Uniwersytetu Jagiellońskiego
}

79 artykule przedstawiono nowy kierunek - zarząadzanie informacją - prowadzony w Instytucie Informacji Naukowej i Bibliotekoznawstwa na Wydziale Zarządzania i Komunikacji Społecznej Uniwersytetu Jagiellońskiego od roku akademickiego 2014/2015. Omówiono też historyczny rozwój programów studiów (1 i 2 stopnia oraz jednolitych magisterskich) $\mathrm{w}$ tej jednostce oraz porównano najnowszy kierunek $\mathrm{z}$ innymi prowadzonymi na uczelniach polskich $\mathrm{w}$ dyscyplinie: bibliologia i informatologia. Ukazano efekty kształcenia określone przez wiedzę, umiejętności oraz kompetencje społeczne, które zostały zaplanowane dla studiów licencjackich i magisterskich. Zaprezentowano także najważniejsze zagadnienia poruszane $\mathrm{w}$ trakcie zajęć.

Charakterystyka studiów na zarządzaniu informacją a zwłaszcza ich porównanie z innymi programami, powstała po analizie opisów kierunków studiów, ich programów i planów, a także profili absolwentów, które zaprezentowane zostały na stronach internetowych polskich jednostek prowadzących studia w dyscyplinie bibliologia i informatologia, nazywanych najczęściej informacją naukową i bibliotekoznawstwem (INIB). Wzięto pod uwagę uczelnie prowadzące studia': Uniwersytet Łódzki

${ }^{1} \mathrm{~W}$ celu zaprezentowania najnowszych danych poddano analizie przede wszystkim informacje dla kandydatów na studia oraz informacje o kierunkach z roku akademickiego 2014/2015 oraz plany dla 2015/2016. Wcześniejsze analizy odnaleźć można w artykule M. Janiak: Akademickie kształcenie bibliologów i informatologów. „Forum Bibliotek Medycznych” 2014 nr 1, s. 17-29. 
(Katedra Bibliotekoznawstwa i Informacji Naukowej na Wydziale Filologicznym); Uniwersytet Marii Curie-Skłodowskiej w Lublinie (Instytut Bibliotekoznawstwa i Informacji Naukowej na Wydziale Humanistycznym); Uniwersytet Mikołaja Kopernika w Toruniu (Instytut Informacji Naukowej i Bibliologii na Wydziale Nauk Historycznych); Uniwersytet Pedagogiczny im. Komisji Edukacji Narodowej w Krakowie (Instytut Informacji Naukowej i Bibliotekoznawstwa na Wydziale Filologicznym); Uniwersytet Śląski w Katowicach (Instytut Bibliotekoznawstwa i Informacji Naukowej na Wydziale Filologicznym); Uniwersytet Warszawski (Instytut Informacji Naukowej i Studiów Bibliologicznych na Wydziale Historycznym); Uniwersytet Wrocławski (Instytut Informacji Naukowej i Bibliotekoznawstwa na Wydziale Filologicznym).

Dodatkowo przeanalizowano informacje o kierunkach i specjalnościach zaproponowanych na innych uczelniach. I tak na Uniwersytecie w Białymstoku w Instytucie Filologii Polskiej dla filologii polskiej zaoferowano specjalności dla studiów 1 stopnia: współczesne bibliotekarstwo i informacja naukowa oraz specjalność edytorską, a dla 2 stopnia: specjalność informacyjno-księgoznawczą oraz edytorstwo cyfrowe. $\mathrm{Na}$ Uniwersytecie Kazimierza Wielkiego w Bydgoszczy, w Katedrze Informacji Naukowej i Bibliotekoznawstwa na Wydziale Administracji i Nauk

50 Społecznych ogłoszono rekrutację na studia informacji naukowej i bibliotekoznawstwa 1 stopnia stacjonarne i niestacjonarne, prowadzone także w trybie popołudniowym (stacjonarne) np. na kandydatów 40+, chcących pogodzić pracę i dokształcanie się. Informację naukową i bibliotekoznawstwo (3-letnie studia pierwszego stopnia) zaproponowano także kandydatom w Wyższej Szkole Umiejętności Społecznych w Poznaniu na Wydziale Prawa i Komunikacji Społecznej. Uniwersytet Zielonogórski w Instytucie Filologii Polskiej otworzył nowy kierunek: filologiczna obsługa internetu i e-edytorstwo (studia stacjonarne 1 stopnia). Pokrewnym jest także kierunek: inżynieria danych (studia stacjonarne 2 stopnia), który rozpocznie się na tej uczelni od semestru letniego w 2016 r. Na Uniwersytecie Jana Kochanowskiego w Kielcach na Wydziale Humanistycznym zaproponowano studia 1 stopnia: informacja w przestrzeni publicznej, które oferują specjalności: broker informacji, e-publikacja, informacja w edukacji i kulturze oraz terapia przez media.

Zaznaczyć należy, iż część uczelni państwowych nadal prowadzi nabór na studia: informacja naukowa i bibliotekoznawstwo. Są to: Uniwersytet Łódzki (studia 1 i 2 stopnia, Katedra Bibliotekoznawstwa i Informacji Naukowej we współpracy z Instytutem Filologii Polskiej oraz Instytutem Kultury Współczesnej), Uniwersytet Pedagogiczny w Krakowie (studia 1 i 2 stopnia, także studia niestacjonarne), Uniwersytet Śląski w Katowicach (studia 1 i 2 stopnia, także studia niestacjonarne), 
Uniwersytet Warszawski (studia 1 i 2 stopnia, także studia niestacjonarne oraz studia równoległe ${ }^{2}$ ), Uniwersytet Wrocławski (studia 1 i 2 stopnia, także studia niestacjonarne).

W związku z możliwością tworzenia przez uczelnie, które posiadają odpowiednie uprawnienia i kadrę, nowych kierunków dla dyscypliny bibliologia i informatologia powstały: informacja w e-społeczeństwie (Lublin - studia 1 stopnia), informatologia stosowana (Lublin - studia 1 i 2 stopnia), zarządzanie informacją i bibliologia (Torun - studia $1^{3}$ i 2 stopnia), publikowanie cyfrowe i sieciowe (Wrocław - studia 1 stopnia), architektura informacji (Kraków, UP - studia 1 stopnia), informacja w instytucjach e-społeczeństwa (Katowice - studia 1 stopnia) ${ }^{4}$, informacja w środowisku cyfrowym (Łódź - studia 1 stopnia).

$\mathrm{Na}$ wielu tych kierunkach studenci mogą wybierać zajęcia z różnych specjalności i specjalizacji. Na studiach licencjackich mają do wyboru:

1) bloki specjalistyczne: wirtualne instytucje kultury; zarządzanie informacją - IŚC - Łódź (dla INIB nie ma specjalizacji);

2) bloki przedmiotów specjalistycznych: informacja w administracji i gospodarce; informacja w kulturze i mediach; informacja w nauce i edukacji - Lublin (kierunek: informacja w e-społeczeństwie);

3) bloki przedmiotów specjalistycznych: zarządzanie na rynku wydawniczo-księgarskim; zarządzanie zasobami prasowymi; zarządzanie $\mathrm{w}$ placówkach informacyjnych - Lublin (kierunek: informatologia stosowana);

4) specjalności: infobrokering i zarządzanie usługami biblioteczno-informacyjnymi; edytorstwo i rynek książki - Toruń;

5) specjalności: społeczeństwo informacji i wiedzy oraz książka dawna - Bydgoszcz;

6) specjalności: biznes i turystyka (zajęcia prowadzone w języku rosyjskim); broker informacji; edukacja interkulturowa; filozofia praktyczna; genderstudies i tożsamość płci; język niemiecki w administracji, handlu i usługach; nauczanie języka polskiego jako obcego; pisanie kreatywne; polityka bezpieczeństwa i wojskowości; polityka regionalna i samorządowa; relacje międzynarodowe; traduktologia (zajęcia prowadzone w języku francuskim); translatoryka (zajęcia prowadzone w języku angielskim); translatoryka (zajęcia prowadzone w języku niemieckim); translatoryka

${ }^{2}$ Limity przyjęć studentów na te studia to 3 osoby.

${ }^{3}$ Dla studiów 1 stopnia przygotowano z zakresu zarządzania informacją i bibliologii od roku akademickiego 2015/2016 grupę popołudniową dla osób, które chciałyby połączyć pracę z nauką.

${ }^{4}$ Na rok akademicki 2015/2016 brak w wykazie kierunków dla kandydatów na studia: infobrokerstwo, zarządzanie dokumentacją i archiwistyka (UP, Instytut Historii - studia 1 stopnia).Perspektywy zawodowe brokera informacji wymienione są w opisie kierunku: doradztwo filozoficzne i coaching, prowadzonym na Wydziale Nauk Społecznych. 
(zajęcia prowadzone $\mathrm{w}$ języku rosyjskim); zarządzanie dokumentacją w urzędzie i firmie - Zielona Góra;

7) bloki przedmiotów: wiedza ogólnohumanistyczna; wiedza o literaturze; podstawy bibliologii i informatologii; organizacja dostępu do informacji oraz bibliotekarstwo - Katowice.

Na studiach 2 stopnia realizowane są specjalizacje i specjalności:

1) specjalność nauczycielska - Kraków, UP;

2) specjalizacje: nowoczesna biblioteka; biblioteka w społeczności lokalnej; zarządzanie informacją; młody czytelnik w świecie książki i mediów; ochrona i konserwacja zbiorów bibliotecznych; kultura i edytorstwo książki - Katowice;

3) specjalizacje: bibliologiczne dziedzictwo kulturowe; cyfrowe zasoby informacji; zarządzanie zasobami informacyjnymi w instytucji publicznej - Lublin (kierunek: informatologia stosowana);

4) specjalizacje: broker informacji; biblioteki naukowe; biblioteki publiczne; bibliotekoznawstwo oraz dodatkowo specjalizacja: dydaktyczna - Łódź;

5) specjalności: biblioterapia; dziedzictwo kulturowe książki; prasoznawstwo; zarządzanie informacją - Toruń;

6) ścieżki: architektura informacji i wiedzy; dziedzictwo kulturowe;

52 edytorstwo; informacja i komunikacja w europejskich instytucjach kultury; informacja w biznesie; internet; organizacja i zarządzanie bibliotekami; zarządzanie informacją i wiedzą - Warszawa;

7) specjalności: biblioteki cyfrowe; biblioteki naukowe; biblioteki w społeczeństwie wiedzy; edytorstwo; prasa w systemie komunikacji społecznej; sztuka książki na studiach stacjonarnych oraz biblioteki publiczne i szkolne; edytorstwo; prasa w systemie komunikacji społecznej na studiach niestacjonarnych - Wrocław.

W Warszawie proponowany jest dodatkowo także blok przygotowania pedagogiczno-psychologicznego.

Jak wynika z tego wykazu, studia bibliotekoznawstwa i informacji naukowej na przestrzeni lat bardzo zmieniły swoje oblicze. Częściowo związane jest to z samymi jednostkami prowadzącymi kształcenie akademickie. Część z nich ulokowana jest na wydziałach humanistycznych, filologicznych, część na wydziałach historycznych lub nauk społecznych. INIB UJ wchodzi w skład Wydziału Zarządzania i Komunikacji Społecznej. $Z$ tego wynikają m.in. różnice w programach i akcentowanie badań historycznych, analiz tekstu, zarządzania informacją itp. Drugim czynnikiem, który zmienił kierunki studiów, tym razem zewnętrznym, jest rozwój technologii. Trzecim są zmiany na rynku pracy: przeobrażenia strukturalne w samych bibliotekach i innych ośrodkach informacji, tworzenie się firm infobrokerskich, jednostek zarządzających informacją oraz publi- 
kujących w sieci, wymogi digitalizacji i ucyfrowienia społeczeństwa, potrzeby użytkowników, konieczność ich uczenia, jak radzić sobie z szumem informacyjnym i nadmiarem informacji np. poprzez budowę nowych systemów informacyjno-wyszukiwawczych itp.

Stąd absolwenci studiów z dyscypliny bibliologia i informatologia powinni być specjalistami z zakresu: informacji naukowej, infobrokeringu, bibliotekarstwa, archiwistyki, księgarstwa, edytorstwa i zagadnień wydawniczych, nowoczesnych mediów, biblioterapii. Mogą zostać: bibliotekarzami wszystkich typów bibliotek, także cyfrowych, brokerami informacji, pracownikami ośrodków i centrów informacji, wydawnictw, księgarni, archiwistami czy też mogą współtworzyć nowe media, także społecznościowe.

Na Uniwersytecie Jagiellońskim zaproponowano kierunek: bibliotekoznawstwo i informacja naukowa od roku akademickiego 1974/1975. Prowadzony był on w ramach Instytutu Filologii Polskiej na Wydziale Filologicznym. Od tego roku (1974) istniał Zakład, a od 1992 r. Katedra Bibliotekoznawstwa i Informacji Naukowej. Instytut Bibliotekoznawstwa i Informacji Naukowej został otworzony w 1996 r. na Wydziale Zarządzania i Komunikacji Społecznej, który utworzony został w tym samym czasie. Obecną nazwę: Instytut Informacji Naukowej i Bibliotekoznawstwa jednostka przyjęła w 2002 r. W tym też roku (2002) w wyniku akredytacji Uniwersyteckiej Komisji Akredytacyjnej placówka otrzymała Certyfikat Jakości Kształcenia przyznany przez Konferencję Rektorów Uniwersytetów Polskich. W 2003 r. zmieniona została nazwa kierunku na: informacja naukowa i bibliotekoznawstwo. Ten kierunek w 2007 r. uzyskał pozytywne oceny Państwowej Komisji Akredytacyjnej oraz Uniwersyteckiej Komisji Akredytacyjnej. W tym samym roku Wydział Zarządzania i Komunikacji Społecznej UJ otrzymał uprawnienia do nadawania stopnia naukowego doktora nauk humanistycznych w dyscyplinie bibliologia i informatologia. Od roku akademickiego 2014/2015 Instytut oferuje nowy kierunek studiów: zarządzanie informacją o profilu ogólnoakademickim.

Od roku akademickiego 1999/2000 wprowadzony został dwustopniowy tryb studiów: studia 1 stopnia, kończące się dyplomem licencjata, oraz studia 2 stopnia, umożliwiające zdobycie tytułu magistra. Jednocześnie z wprowadzaniem Ramowych Ram Kwalifikacji rozpoczęto implementowanie europejskiego systemu punktów ECTS. Od roku akademickiego 2008/2009 prowadzone są również studia 3 stopnia (doktoranckie) w dziedzinie nauki humanistyczne, w dyscyplinie bibliologia i informatologia.

Studentom oferowane były zarówno studia dzienne, jak i zaoczne. Od roku 1981 prowadzono również studia podyplomowe: broker informacji; 
bibliotekoznawstwo (2- i 3-semestralne, doskonalące); informacja naukowa; informacja naukowa - broker informacji; bibliotekoznawstwo - bibliotekarz dziedzinowy; bibliotekoznawstwo i informacja naukowa oraz informacja naukowa - wyszukiwanie informacji.

W latach 2013/2014 i 2014/2015 przedstawiono także propozycje krótkich kursów dokształcających: doskonalenie percepcji informacji; media społecznościowe w bibliotekach; praktyka tworzenia bibliotek cyfrowych; komunikacja $\mathrm{z}$ klientem $\mathrm{w}$ sektorze informacyjnym. Studia stacjonarne i niestacjonarne 1 i 2 stopnia informacji naukowej i bibliotekoznawstwa oraz kursy dokształcające zostały zlikwidowane od roku akademickiego 2014/2015 (z chwilą ich wygaśnięcia).

Nowy kierunek studiów - zarządzanie informacją - został zaproponowany po analizach własnych programów (które ulegały różnorodnym zmianom w czasie) oraz tendencji światowych w kształceniu w dyscyplinie bibliologia i informatologia, a także wysnuciu wniosków z dyskusji prowadzonych w gronie pracowników INIB UJ, pracodawców i przedstawicieli studentów. Ustalono, iż kierunek zarządzanie informacją składać się będzie z zajęć, podczas których

humanistyczna wiedza o relacjach między człowiekiem i informacją łączona

jest z kształtowaniem umiejętności technicznych i rozwijaniem kompetencji społecznych ${ }^{5}$.

Stąd studenci zapoznają się z funkcjonowaniem środowiska informacyjnego człowieka, a więc $\mathrm{z}$ jednej strony poznają profesjonalne źródła informacji (dane), a z drugiej zasady i sposoby skutecznego przeszukiwania i organizowania kolekcji (struktury, ocena jakości). Do tego dochodzi nauka o zachowaniach informacyjnych wszystkich użytkowników (od twórców, poprzez administratorów i badaczy, po użytkowników końcowych) oraz o tym, jak efektywnie zarządzać informacją $w$ instytucjach i przedsiębiorstwach. Ponadto studenci studiów magisterskich uczeni są samodzielnego oceniania i projektowania rozwiązań informacyjnych usprawniających działalność człowieka oraz realizowania różnorodnych działań poznawczych związanych z zarządzaniem informacją. Jednocześnie studenci poznają dorobek bibliologii i informatologii oraz metody badawcze pozwalające na naukowe rozwiązywanie problemów profesjonalnych i prowadzenie badań. Tak więc problematyka naukowa łączona jest $\mathrm{z}$ profesjonalną.

Wszystkie te tematy, które omawiane są w trakcie studiów, mają na celu przygotowanie absolwenta do opracowywania i realizacji za-

${ }^{5}$ Instytut Informacji Naukowej i Bibliotekoznawstwa. http://www.inib.uj.edu.pl [dostęp 15.07.2015]. 
awansowanych zadań profesjonalnych, których podejmować się będą $\mathrm{w}$ swojej przyszłej pracy $\mathrm{w}$ instytucjach i organizacjach działających w sferze komunikacji publicznej, kultury, edukacji, biznesu, nauki i administracji. Rozwój kariery zawodowej absolwentów może bowiem iść w wielu kierunkach. Przede wszystkim nadal pracować mogą w różnorodnych ośrodkach informacji, bibliotekach wszelkiego typu (naukowych i akademickich, publicznych, szkolnych, fachowych, kościelnych itp.), czy też w instytucjach kultury (zwłaszcza w wydawnictwach, księgarniach czy domach kultury). Mogą wykonywać usługi informacyjne dla nauki, edukacji, biznesu i administracji, gdyż przygotowywani są do pracy w zawodach: brokera informacji, researchera czy analityka informacji. Uczeni są także, jak zarządzać informacją potrzebną do życia codziennego, jak ją wyszukiwać z systemów ogólnych, specjalistycznych, instytucjonalnych, społecznościowych, a także jak ją oceniać. Mogą wspierać zróżnicowane działania człowieka, a więc pracować $\mathrm{w}$ charakterze specjalisty zarządzania informacją czy menedżera informacji. W związku z otworzeniem nowej specjalizacji absolwenci wiedzą, jak transferować informację w społeczeństwie, zorganizować dane, przetworzyć je dla różnych grup interesariuszy obszaru nauki, techniki, gospodarki i kultury, zdiagnozować potrzeby i zrealizować przepływ informacji. Studenci nadal uczą się, jak tworzyć i zarządzać różnymi kolekcjami cyfrowymi, nie tylko dokumentów, ale także plików multimedialnych. Wiedza ta przydaje się do zarządzania obiegiem dokumentów elektronicznych w firmach i instytucjach np. kultury, a także do digitalizacji istniejących zasobów informacyjnych i ich upubliczniania w środowisku sieciowym. Absolwenci mogą więc zajmować się organizacją i prowadzeniem cyfrowych archiwów; repozytoriów, bibliotek cyfrowych i wirtualnych, baz wiedzy, banków danych itp.

Studia 1 stopnia na kierunku zarządzanie informacją przygotowują studenta do podejmowania

naukowych działań poznawczych w odniesieniu do szerokiej grupy zjawisk i procesów, od tych warunkujących poszukiwanie informacji, poprzez jej pozyskiwanie, gromadzenie, opracowanie i przetwarzanie, do udostępniania i wykorzystania przez człowieka, a także do realizacji zadań profesjonalnych związanych z zarządzaniem informacją $\mathrm{w}$ różnych instytucjach i organizacjach, zajmujących się gromadzeniem, opracowaniem i udostępnianiem informacji i dokumentów oraz dorobku kulturowego człowieka ${ }^{6}$.

\footnotetext{
${ }^{6}$ Ibidem.
} 
Ten aspekt profesjonalny jest elementem, na który położony został największy nacisk. Studia 1 stopnia są bowiem traktowane jako studia „zawodowe”, gdyż w świetle ustawy Polska Klasyfikacja Edukacji (PKE) ich absolwent zdobywa wykształcenie wyższe zawodowe.

Przygotowane dla kierunku efekty kształcenia odnoszą się do obszaru nauk humanistycznych. Standardowo podzielono je na efekty dotyczące wiedzy, umiejętności i kompetencji społecznych, wyodrębniając te najbardziej ogólne elementy:

1) znajomość znaczenia i roli nauk humanistycznych w poznaniu zjawisk z zakresu zarządzania informacją i w doskonaleniu działalności praktycznej w tym względzie;

2) posługiwanie się podstawową terminologią naukową i profesjonalną z zakresu bibliologii i informatologii oraz innych nauk humanistycznych;

3) znajomość bibliologii i informatologii jako dyscypliny naukowej dostarczającej podstaw teoretycznych, metod i rozwiązań dla praktyki zarządzania informacją oraz

4) określanie relacji między bibliologią i informatologią a innymi dyscyplinami z obszaru nauk humanistycznych, pozwalające na interdyscyplinarne podejście do działań naukowych i profesjonalnych;

5) znajomość dorobku tej dyscypliny oraz innych pokrewnych, w zakresie istotnym dla planowania i realizacji działań poznawczych i praktycznych w obszarze zarządzania informacją;

6) znajomość aktualnych trendów, dylematów i kierunków rozwoju bibliologii i informatologii oraz dyscyplin pokrewnych w zakresie istotnym dla badań podstawowych i stosowanych w obszarze zarządzania informacja;

7) identyfikacja i objaśnianie aktualnie stosowanej metodyki wykonywania zadań, norm, procedur, narzędzi, technologii i dobrych praktyk stosowanych w zarządzaniu informacją;

8) znajomość i rozumienie najważniejszych sposobów poznania i interpretacji zjawisk zachodzących w środowisku informacyjnym, zachowań informacyjnych jego uczestników oraz dostępnych w nim obiektów, kolekcji, systemów, usług, narzędzi i produktów informacyjnych; rozeznania i rozumienia podstawowych pojęć. Ważna jest też znajomość porządkowania i przedstawiania podstawowych źródeł informacji naukowej oraz profesjonalnej.

Do tego dochodzi wiedza z zagadnień prawnych, zwłaszcza regulacji i zasad z zakresu ochrony własności intelektualnej i prawa autorskiego oraz prawnych uwarunkowań działalności z zakresu zarządzania informacją. Inne istotne kwestie poruszane $w$ trakcie zajęć to: 1) objaśnianie roli i zastosowania różnych języków (naturalnego, sztucznych) w szeroko ro- 
zumianym zarządzaniu informacją; 2) aspekty współczesnej kultury oraz zasady i możliwości uczestnictwa w życiu kulturalnym; 3) historia, cele, organizacja i funkcjonowanie instytucji i organizacji działających w sferze kultury i nauki ze szczególnym uwzględnieniem tych zajmujących się gromadzeniem, opracowaniem, przechowywaniem i udostępnianiem informacji.

Umiejętności, które zdobywają studenci, opisane zostały poprzez kwalifikacje odnoszące się do teorii. Są to:

1) formułowanie problemów badawczych (z pomocą nauczyciela akademickiego), dobieranie odpowiednich metod ich rozwiązywania i formy prezentowania wyników w odniesieniu do problemów poznawczych i stosowanych szeroko rozumianego zarządzania informacją z perspektywy bibliologii i informatologii;

2) samodzielne zdobywanie nowej wiedzy i umiejętności służących naukowemu rozwiązywaniu problemów poznawczych i profesjonalnych zarządzania informacją $\mathrm{w}$ tym działalności informacyjnej, bibliotekarstwa, działalności wydawniczo-księgarskiej i archiwalnej;

3) posługiwanie się podstawowymi paradygmatami, koncepcjami teoretycznymi i pojęciami funkcjonującymi w bibliologii i informatologii oraz naukach pokrewnych, pozwalającymi na ujmowanie różnych problemów poznawczych i stosowanych związanych z badaniami i praktyką zarządzania informacją;

4) rozpoznawanie różnych rodzajów zachowań i potrzeb informacyjnych człowieka, zdolność ich interpretacji w odniesieniu do dorobku bibliologii i informatologii i nauk pokrewnych, stosując typowe podejścia i metody diagnostyczne.

Do tego dochodzą umiejętności praktyczne:

1) sprawne odnajdowanie, ocenianie i wybieranie informacji relewantnych w stosunku do sytuacji problemowej i potrzeby informacyjnej w źródłach różnego typu i w różnej formie, stosowanie adekwatnych strategii wyszukiwawczych, efektywne wykorzystanie nowoczesnych technologii informacyjnych i komunikacyjnych;

2) analizowanie, ocenianie i realizowanie typowych systemów, produktów, obiektów, narzędzi i usług informacyjnych oraz procesów zarządzania informacją w kontekście konkretnych sytuacji społecznych i potrzeb indywidualnych;

3) formułowanie i uzasadnianie prezentowanych opinii i wniosków, powołując się na dorobek bibliologii i informatologii, dyscyplin pokrewnych oraz profesji związanych z zarządzaniem informacją

4) porozumiewanie się $z$ wykorzystaniem różnych kanałów i technik komunikacyjnych ze specjalistami z zakresu bibliologii i informatologii oraz dyscyplin pokrewnych; 
5) opracowywanie samodzielnych typowych prac pisemnych na temat różnych aspektów szeroko rozumianego zarządzania informacją;

6) przygotowywanie i wygłaszanie krótkich prezentacji na wybrany temat naukowy bądź profesjonalny, właściwie udokumentowanych i osadzonych w dorobku naukowym lub profesjonalnym;

7) komunikowanie się $w$ języku nowożytnym obcym na poziomie zgodnym z wymaganiami określonymi dla poziomu B2 Europejskiego Systemu Opisu Kształcenia Językowego.

Natomiast ostatnie $\mathrm{w}$ triadzie: kompetencje społeczne to przede wszystkim:

1) uświadamianie sobie konieczności permanentnego rozwijania swojej wiedzy i umiejętności w odpowiedzi na nowe osiągnięcia nauki, zmiany zachodzące w środowisku informacyjnym oraz zmiany zachowań informacyjnych człowieka;

2) realizowanie powierzonych zadań poznawczych oraz związanych z praktyczną stroną zarządzania informacją; świadome planowanie działań, wskazując czynniki ich powodzenia i przyjmując odpowiedzialność za ich właściwe wykonanie, konsekwencje i za wizerunek wykonywanego przez siebie zawodu;

3) podejmowanie prób rozwiązania napotykanych problemów profe58 sjonalnych $\mathrm{w}$ zakresie zarządzania informacja, odwołując się do dorobku nauki, najlepszych praktyk profesjonalnych oraz zasad postępowania przyjętych w profesjach informacyjnych;

4) uczestniczenie $\mathrm{w}$ różnych formach życia kulturalnego i naukowego, realizowanych za pośrednictwem różnych mediów, związanych przede wszystkim z szeroko rozumianą sferą kultury piśmienniczej.

Do tego dochodzi jeszcze: świadomość znaczenia szeroko rozumianego zarządzania informacja, w tym działalności informacyjnej, bibliotecznej, wydawniczo-księgarskiej i archiwalnej, dla funkcjonowania współczesnego społeczeństwa i zachowania dziedzictwa kulturowego regionu, kraju i Europy ${ }^{7}$.

Cele kształcenia można także zaprezentować za pomocą tematyki zajęć prowadzonych w trakcie całych studiów, które da się podzielić na nieformalne bloki, odnoszące się do zarówno do bibliologii, jak i do informatologii. Bazowym przedmiotem są: podstawy teorii i metodologii bibliologii i informatologii. Zestaw zajęć bibliologicznych stanowią: podstawy bibliotekarstwa; czytelnictwo i recepcja informacji; formalne opracowanie informacji; kolekcje zasobów informacyjnych i kultura książki w dziejach; zarządzanie informacją w bibliotekach; wielkie biblioteki i ich historia; zachowanie dziedzictwa kulturowego: książka, biblioteka, archi-

${ }^{7}$ Efekty kształcenia zostały przedstawione zgodnie z programem studiów. 
wum; zagadnienia wydawnicze i księgarskie; dydaktyka czytelnicza i informacyjna; książka dla dzieci i młodzieży; informacja edukacyjna.

Do podstawowych modułów informatologicznych zaliczyć należy: źródła informacji; ochrona własności intelektualnej; wstęp do archiwizacji i cyfryzacji informacji; projektowanie i ocena systemów informacji; języki informacyjno-wyszukiwawcze i indeksowanie; organizacja informacji i wiedzy; elementy bibliometrii; zarządzanie obiegiem dokumentów; wizualizacja informacji; estetyka a informacja oraz wykłady fakultatywne: informatologia jako nauka interdyscyplinarna; informatologiczne koncepcje ekologii informacji. Do tego wykazu dodać jeszcze należy przedmioty związane z użytkownikami informacji: środowisko informacyjne człowieka; komunikacja społeczna i media; zachowania informacyjne; kompetencje informacyjne $\mathrm{w}$ rozwoju indywidualnym i społecznym; usługi i produkty informacyjne; umiejętności psychospołeczne w profesjach informacyjnych; emocje w zachowaniach informacyjnych.

Osobny blok stanowią zajęcia związane z samym zarządzaniem, takie jak: podstawy zarządzania; wstęp do zarządzania informacją; podstawy zarządzania informacją $\mathrm{w}$ nauce; zarządzanie informacją $\mathrm{w}$ organizacji. Ogólne moduły to: naukoznawstwo; metodologia nauk; czy literatura. Do tego wymienić jeszcze należy: praktykę, zajęcia terenowe czy projekty profesjonalne wymagające samodzielnej pracy studentów.

Studenci mogą także zdobyć uprawnienia pedagogiczne, które umożliwiają prowadzenie zajęć w szkołach podstawowych.

Studia 2 stopnia pogłębiają wiedzę na temat znaczenia i roli nauk humanistycznych $\mathrm{w}$ poznaniu zjawisk $\mathrm{z}$ zakresu zarządzania informacją oraz pozwalają w sposób twórczy stosować ją w działalności profesjonalnej. Dodatkowo

porządkują i pogłębiają terminologię, wiedzę o teoriach i metodologii z zakresu bibliologii i informatologii oraz innych nauk humanistycznych $\mathrm{w}$ odniesieniu do zagadnień $\mathrm{z}$ obszaru szeroko rozumianego zarządzania informacją; poszerzają wiedzę na temat bibliologii i informatologii jako dyscypliny naukowej,

dostarczając przy tym

podstaw teoretycznych, metod i rozwiązań dla praktyki zarządzania informacją, w tym dla bibliotekarstwa, działalności informacyjnej, wydawniczo-księgarskiej i archiwalnej, oraz na temat podstawowych humanistycznych aspektów nauk o zarządzaniu

oraz pozwalają na

twórcze planowanie i realizację działań poznawczych i profesjonalnych w obszarze zarządzania informacja, 
a także na

integrowanie perspektyw właściwych dla problematyki zarządzania informacją ${ }^{8}$.

Według efektów kształcenia studenci mają też: szczegółową wiedzę o współczesnych dokonaniach i kierunkach rozwoju, ośrodkach i szkołach badawczych bibliologii i informatologii oraz dyscyplin pokrewnych w zakresie istotnym dla badań podstawowych i stosowanych w obszarze zarządzania informacją. Dodatkowo znają i rozumieją zaawansowane metody analizy, interpretacji, wartościowania, problematyzowania stosowane w zarządzaniu informacja, a także metodykę wykonywania zadań, normy, procedury, narzędzia, technologie i dobre praktyki stosowane w działalności informacyjnej, bibliotecznej, archiwalnej i wydawniczo-księgarskiej oraz heterogeniczne sposoby poznania i interpretacji zjawisk zachodzacych we współczesnym środowisku informacyjnym, zachowań informacyjnych jego uczestników oraz dostępnych w nim obiektów, kolekcji, systemów, usług i produktów informacyjnych. Wiele efektów kształcenia odnosi się do instytucji. Stąd studenci mają: 1) pogłębioną wiedzę na temat wybranych aspektów współczesnej kultury oraz zasad i możliwości aktywnego uczestnictwa w życiu kulturalnym; o historii oraz o współczesnych celach i funkcjonowaniu instytucji i organizacji działających w sferze kultury ze szczególnym uwzględnieniem tych zajmujących się gromadzeniem, opracowaniem, przechowywaniem i udostępnianiem informacji oraz 2) potrafią określić zasady funkcjonowania instytucji informacji w systemie kultury, jak i ekonomiczne przesłanki decyzji dotyczących zachowań nabywców i dostawców na rynku informacji. Dodatkowo znają i rozumieją: 3) pojęcia, regulacje i zasady z zakresu ochrony własności intelektualnej i prawa autorskiego oraz identyfikują prawne uwarunkowania działalności z zakresu zarządzania informacją, a także konieczność zarządzania zasobami własności intelektualnej. Także języki: naturalne i sztuczne są ważne w trakcie nauczania. Wśród efektów kształcenia zapisano więc, iż studenci posiadają wiedzę o: 4) naturze języka, różnych języków, historycznej zmienności znaczeń ważnych dla szeroko rozumianego zarządzania informacja, w tym także komunikowania, organizacji wiedzy i recepcji przekazów kulturowych. Ponadto absolwent studiów potrafi scharakteryzować: 5) polskie i zagraniczne źródła informacji naukowej z obszaru bibliologii i informatologii oraz informacji profesjonalnej z zakresu zarządzania informacja, a także z dyscyplin pokrewnych i obszarów profesjonalnych oraz 6) precyzyjnie i wyczerpująco wyjaśnia miejsce różnych zasobów informacji we współczesnym systemie kultury i mediów.

${ }^{8}$ Ibidem. 
Kolejne z triady efektów kształcenia: umiejętności opisane zostały przez kwalifikacje sprawnego wyszukiwania, oceny i wyboru informacji, które dokonywane są poprzez stosowanie adekwatnych strategii wyszukiwawczych, efektywnego wykorzystania nowoczesnych technologii informacyjnych i komunikacyjnych, a także opracowania uporządkowanych i selektywnych wykazów źródeł informacji na określony temat oraz na tej podstawie formułowania krytycznych ocen stanu badań oraz stanu wiedzy i umiejętności profesjonalnych w obszarze zarządzania informacją. Ponadto studenci:

1) posiadają pogłębione umiejętności badawcze, obejmujące analizę prac innych autorów, syntezę różnych idei i poglądów, dobór metod i konstruowanie narzędzi badawczych, opracowanie i prezentację wyników, pozwalające na oryginalne rozwiązywanie złożonych problemów w zakresie bibliologii i informatologii;

2) samodzielnie zdobywają nową wiedzę i poszerzają umiejętności badawcze służące naukowemu rozwiązywaniu problemów poznawczych i profesjonalnych zarządzania informacja, $w$ tym działalności informacyjnej, bibliotekarstwa, działalności wydawniczo-księgarskiej i archiwalnej, a także podejmują autonomiczne działania zmierzające do rozwijania zdolności i kierowania własną karierą zawodową;

3) posługują się ważnymi dla zarządzania informacją paradygmata$\mathrm{mi}$, koncepcjami teoretycznymi i pojęciami oraz potrafią zastosować je dla działań poznawczych oraz $\mathrm{w}$ różnych sytuacjach profesjonalnych;

4) formułują i uzasadniają merytorycznie własne opinie i wnioski, powołując się na dorobek bibliologii i informatologii, dyscyplin pokrewnych oraz profesji związanych z zarządzaniem informacją a także tworzą syntetyczne podsumowania na podstawie zebranych informacji;

5) posiadają umiejętność formułowania opinii krytycznych o obiektach i systemach informacyjnych na podstawie wiedzy o zarządzaniu informacja, a także porozumiewać się z wykorzystaniem różnych form i mediów komunikacyjnych ze specjalistami z zakresu bibliologii i informatologii oraz dyscyplin pokrewnych, jak i również z użytkownikami docelowymi.

Dodatkowo każdy absolwent:

1) krytycznie analizuje, ocenia i realizuje różne systemy, produkty, obiekty i usługi informacyjne oraz procesy zarządzania informacją w kontekście konkretnych sytuacji społecznych, ich miejsca w procesie historyczno-kulturowym, ale także $\mathrm{w}$ odniesieniu do różnorodnych potrzeb indywidualnych;

2) rozpoznaje zachowania informacyjne użytkowników, potrafi określić ich znaczenia, miejsce w systemie komunikacji społecznej, stosując oryginalne podejścia, interpretując je w odniesieniu do dorobku bibliologii 
i informatologii i nauk pokrewnych, stosując różnorodne podejścia i metody diagnostyczne;

3) opracowuje samodzielnie rozbudowane pisemne projekty naukowe lub profesjonalne $\mathrm{z}$ zakresu szeroko rozumianego zarządzania informacja, odwołując się do samodzielnie sformułowanych problemów i metod ich naukowego rozwiązywania, a także do najważniejszych ujęć teoretycznych i wyników badań naukowych pozyskiwanych z adekwatnych źródeł;

4) przygotowuje i wygłasza dłuższe prezentacje na wybrany temat naukowy bądź profesjonalny z zakresu szeroko rozumianego zarządzania informacja, właściwie udokumentowane i osadzone w dorobku naukowym lub profesjonalnym oraz

5) komunikuje się w języku nowożytnym obcym na poziomie zgodnym z wymaganiami określonymi dla poziomu B2+ Europejskiego Systemu Opisu Kształcenia Językowego.

Dla studiów 2 stopnia określono także wykaz kompetencji społecznych, które student zdobywa w trakcie kształcenia. Są to:

1) rozumienie i akceptacja konieczności permanentnego rozwijania swojej wiedzy i umiejętności w odpowiedzi na nowe osiągnięcia nauki, zmiany zachodzące $\mathrm{w}$ środowisku informacyjnym oraz zmiany zacho-

62 wań informacyjnych człowieka oraz inspirowanie i organizowanie proces uczenia się innych osób;

2) realizowanie powierzonych oraz opracowanych przez siebie zadań poznawczych oraz związanych z praktyczną stroną zarządzania informacją;

3) świadome planowanie działań, przy wskazaniu odpowiednich priorytetów ich powodzenia, przyjmowanie przy tym odpowiedzialności za ich właściwe wykonanie, konsekwencje i za wizerunek wykonywanego przez siebie zawodu;

4) prawidłowa identyfikacja i rozstrzyganie napotykanych problemów naukowych i profesjonalnych $\mathrm{w}$ zakresie zarządzania informacja, odwoływanie się do dorobku nauki, najlepszych praktyk profesjonalnych oraz zasad postępowania przyjętych w profesjach informacyjnych;

5) świadomość znaczenia szeroko rozumianego zarządzania informacja, w tym działalności informacyjnej, bibliotecznej, wydawniczo-księgarskiej i archiwalnej, dla zachowania dziedzictwa kulturowego regionu, kraju i Europy oraz aktywnie uczestniczy w różnorodnych akcjach podejmowanych w tym obszarze oraz

6) systematyczne uczestniczenie $w$ wydarzeniach kulturalnych realizowanych $\mathrm{w}$ różnych formach i za pośrednictwem różnych mediów, związanych przede wszystkim z szeroko rozumianą sferą kultury piśmienniczej, a także umiejętność zainteresowania innych użytkowników oraz przekazywanie w atrakcyjny sposób informacji o nich. 
Podobnie jak zrobiono to dla studiów 1 stopnia, przedstawione obecnie zostaną zajęcia w podziale tematycznym. Pierwszy zestaw to zajęcia podstawowe dla całej dyscypliny: teoria i metodologia bibliologii i informatologii; terminologia bibliologii i informatologii; współczesne problemy i kierunki badań w bibliologii i informatologii; podstawy prawne działalności informacyjnej, bibliotecznej, archiwalnej i wydawniczo-księgarskiej. Do tego dochodzą przedmioty uczące umiejętności zachowania się w pracy, współpracy itp., takie jak: etyka badań i zawodów informacyjnych czy absolwent zarządzania informacją w środowisku zawodowym. Do bibliologii odnosi się przede wszystkim: kultura książki czy przegląd źródeł informacji. Moduły informatologiczne to: zarządzanie informacją wizualną i dźwiękowa; indywidualne zarządzanie informacją; zarządzanie informacją i wiedzą w społeczeństwie; zarządzanie informacją w sektorze nauki, zarządzanie w bibliotekarstwie i praktyce informacyjnej czy PR - strategie przekazywania informacji. Natomiast ogólne przedmioty odnoszące się do zarządzania to: podstawy ekonomii dla zarządzania informacją; podstawy zarządzania instytucjami kultury czy zarządzanie projektami. Ciekawym uniwersalnym przedmiotem jest: obserwatorium kultury, w trakcie którego studenci doskonalą głównie kompetencje społeczne i umiejętności przekazywania danych oraz recenzowania wydarzeń kulturalnych.

Specjalizacje proponowane studentom to: infobrokering i wywiad rynkowy (czyli jak docierać do informacji); transfer informacji w społeczeństwie (nauka, technika, gospodarka) (czyli jak przekazywać informacje); obiekty i kolekcje cyfrowe (czyli jak tworzyć obiekty i zarządzać kolekcjami) oraz bibliotekarstwo - podstawy oraz dydaktyka informacyjna.

Studenci mogą także zdobyć uprawnienia pedagogiczne, które umożliwiają prowadzenie zajęć w szkołach podstawowych (dla osób, które nie zdobyły ich w trakcie studiów 1 stopnia) oraz w szkołach ponadpodstawowych.

W artykule przedstawiono, jak programy studiów prowadzonych dla dyscypliny bibliologia i informatologia ulegają coraz większym modyfikacjom. Dotyczy to wszystkich uczelni, które takie kierunki proponują. Przede wszystkim powstają nowe programy, które kładą nacisk na informatologiczne aspekty dyscypliny. Zgodne jest to z zewnętrznymi uwarunkowaniami: postępem technologicznym oraz zmianami w organizacji jednostek związanych $\mathrm{z}$ tworzeniem, gromadzeniem, przetwarzaniem i udostępnianiem informacji. Także interesariusze wewnętrzni (studenci) są bardziej zainteresowani zdobywaniem wiedzy i umiejętności, które umożliwiają szukanie pracy w większej liczbie instytucji. Stąd absolwenci obecnych kierunków studiów to już nie tylko przyszli bibliotekarze, lecz także informatolodzy, pracownicy informacji czy usług informacyjnych, edytorzy, wydawcy, księgarze, archiwiści, infobrokerzy itp. 
W Instytucie Informacji Naukowej i Bibliotekoznawstwa Uniwersytetu Jagiellońskiego zaproponowano nowy kierunek studiów - zarządzanie informacją - odnosząc się do wszystkich wymienionych uwarunkowań, mając nadzieję, że szerszy zakres osiąganych efektów kształcenia ułatwi absolwentom zdobycie atrakcyjnej i ciekawej pracy oraz pozwoli na dalsze prowadzenie samodzielnych badań naukowych.

\section{Bibliografia}

Janiak M.: Akademickie ksztatcenie bibliologów i informatologów. „Forum Bibliotek Medycznych" 2014 nr 1, s. 17-29.

Uniwersytet Jagielloński w Krakowie, Instytut Informacji Naukowej i Bibliotekoznawstwa. http://www.inib.uj.edu.pl [dostęp 19.07.2015].

Uniwersytet Jana Kochanowskiego w Kielcach, Instytut Dziennikarstwa i Informacji. http://idi.ujk.edu.pl/ [dostęp 21.07.2015].

Uniwersytet Kazimierza Wielkiego w Bydgoszczy, Katedra Informacji Naukowej i Bibliologii. http://www.kinib.ukw.edu.pl/jednostka/katedra_informacji_naukowej/ [dostęp 15.07.2015].

64 Uniwersytet Łódzki, Katedra Bibliotekoznawstwa i Informacji Naukowej. http:// www.kbin.uni.lodz.pl/kbin/ [dostęp 21.07.2015].

Uniwersytet Marii Curie-Skłodowskiej w Lublinie, Instytut Informacji Naukowej i Bibliotekoznawstwa. http://www.umcs.pl/pl/inib.htm [dostęp 21.07.2015].

Uniwersytet Mikołaja Kopernika w Toruniu, Instytut Informacji Naukowej i Bibliologii. http://www.inibi.umk.pl/ [dostęp 15.07.2015].

Uniwersytet Pedagogiczny im. Komisji Edukacji Narodowej w Krakowie, Instytut Informacji Naukowej i Bibliotekoznawstwa. http://iinib.up.krakow.pl/ [dostęp 15.07.2015].

Uniwersytet Śląski w Katowicach, Instytut Bibliotekoznawstwa i Informacji Naukowej. http://ibin.us.edu.pl/ [dostęp 15.07.2015].

Uniwersytet Śląski w Katowicach, Studia, Katalog kierunków. https://www.irk. us.edu.pl/ [dostęp 15.07.2015].

Uniwersytet w Białymstoku. Instytut Filologii Polskiej. http://ifp.uwb.edu.pl/index. php?option=com_content\&view=article\&id=67\&Itemid=139 [dostęp 15.07.2015].

Uniwersytet Warszawski, Instytut Informacji Naukowej i Studiów Bibliologicznych. http://www.lis.uw.edu.pl/ [dostęp 15.07.2015].

Uniwersytet Wrocławski, Instytut Informacji Naukowej i Bibliotekoznawstwa. http://www.ibi.uni.wroc.pl/ [dostęp 15.07.2015].

Uniwersytet Zielonogórski, Rekrutacja. Wyższa Szkoła Umiejętności Społecznych w Poznaniu. http://wsus.pl/pl [dostęp 15.07.2015]. 
Information Management: The changes in the academic education in Institute of Information and Library Science of the Jagiellonian University

The aim of this paper is to present the changes in the academic education of librarians and specialist of information science which occurred in Institute of Information and Library Science of the Jagiellonian University. Since 2014/2015 the Institute offers undergraduate and graduate degree programmes in Information Management and conduct research in a vast area of Book and Information Science with a special emphasis on various aspects of theory and methodology of this discipline, information management, behaviour, culture and competencies as well as on books and their functions in social communication and on modern librarianship.

Keywords: information management, academic education of librarians, academic education of specialist of information science, Institute of Information and Library Science Jagiellonian University 